\title{
FOSTERING ENTREPRENEURSHIP AT HIGH SCHOOLS: A CASE OF RURAL AREAS IN VOJVODINA (SERBIA)
}

\author{
Slavica Otovićn ${ }^{1}$ Dunja Demirović², Kristina Košič́c, Aleksandra Vujko ${ }^{4}$
}

\begin{abstract}
Summary
An early entrepreneurial education has a positive influence on decisions of young people to engage in entrepreneurial activities. Long term unemployment among young people is a characteristic of Republic of Serbia. The youth unemployment can be decreased by directing and encouraging young people to start their own businesses, but shaping the entrepreneurial aspirations should take primacy. These aspirations must be founded on knowledge, skills, social involvement and networking. Educational system should be adjusted to follow economic and market shifts. In this paper, research was conducted in four high schools in rural municipalities of Autonomous Province of Vojvodina. The pupils were given a questioner regarding their entrepreneurial aspirations. Based on the collected data, measures for altering and complementing curriculums in high schools can be designed. Early entrepreneurial education is helping young population to build their careers on realistic grounds and compatible with ongoing global trends.
\end{abstract}

Key words: entrepreneurship, unemployment, education, young people, Vojvodina (Serbia)

JEL: $Q 13, Q 15$

\section{Introduction}

In modern economy, entrepreneurship is viewed as an important component in industry, next to land, work and capital. The definition of entrepreneurship includes proactive,

1 Slavica Otović, MSc, Public relations manager, General hospital Vrbas, Dr M. Cekica street, number 4, 21460 Vrbas, Serbia, phone:+38164 802 3215, E-mail: slavicaotovic1@gmail.com

2 Dunja Demirović, Ph.D., Assistant professor, University Business Academy in Novi Sad, Faculty of Economics and Engineering Management in Novi Sad, Cvećarska 2, 21000 Novi Sad, Serbia, phone: +381642686290, E-mail: demirovic.dunja2@gmail.com (corresponding author)

3 Kristina Košić, Ph.D., Associate proffesor, University of Novi Sad, Faculty of Sciences, Department of Geography, Tourism and Hotel Management, Trg Dositeja Obradovića 3, 21000 Novi Sad, Serbia, e-mail: tinicaus@yahoo.com

4 Aleksandra Vujko, Ph.D., Lecturer, Novi Sad Business School, Vladimira Perića Valtera street no. 4, Novi Sad, Serbia, Phone: +381 6491426 45, E-mail: aleksandravujko@yahoo.com

EP 2017 (64) 4 (1523-1535) 
innovation based economic activity of an individual, group of individuals bound with contract (such as joint-stock companies, corporations and even countries in form of public entrepreneurship) (Rusu et al., 2012). Among other initiatives, European Union strongly supports the one regarding rural entrepreneurship. This type of entrepreneurship strives towards rural development sustainability and falls under the second pillar of agrarian politics. Entrepreneurship is a specific feature of an individual, corporation or an institution. Entrepreneurs see a change as an inevitable and a healthy thing.

In accordance with perceptional shift regarding needs of individuals, society and economy and also with aim to improve training for educators and evaluation process, curricula of schools in the EU countries have been revised. All financial and nonfinancial parameters were taken into account (www.europa.eu/eurostat). On the other side, research conducted in Sweden in Norway found a link between participation in youth entrepreneurship programs and establishing personal businesses. The research has shown that 26,7\% of people over the age of 29 who attended "Young entrepreneurs" program the year before started their own business (Napier et al., 2012). Norway is known for its high employment rate among young people aged between 16 and 19 . This might be a result of implementation of entrepreneurship in educational system. This way, the government influenced on strengthening the ability of an individual to seize the opportunities given in industry and other parts of the community (NIC, 2005).

With more education and encouragement, youth should be able to realize their entrepreneurial aspirations. This outcome will increase economic growth in communities and open new job and career opportunities, regardless of economic circumstances. Although not all youth will become entrepreneurs, all students and society benefit when individuals have a solid education, that gives them entrepreneurial knowledge and skills to use over their lifetime (Raposo, do Paço, 2011).

The question of great importance is how high school pupils, future university students in the Republic of Serbia, choose their studies and what influences their decision. To what extent do labour market conditions and enrollment quota influence pupils' choices, bearing in mind that the information regarding demands for certain jobs on labour market is not accessible to the public and that enrollment quota trends have been the same over the years. Radical reforms of the labor market institutions were needed in the Republic of Serbia after the October of 2000. These reforms would be the key to economical efficacy and aim to create employment policies that are compatible with general direction of comprehensive market reform. However, the market reform wasn't designed to fit labor market needs, nor the market was taken into account as an endogenous variable, nor as a significant limitation in the outcomes of strategic directions of the reform (Žarković, Rakić, 2015).

Authors Markov and Mirkov (2006) in their research indicate that Serbia is in the middle of process of shaping students that way that they can see establishing own businesses as a potential career option. Compared to students in western countries, Serbian students have lower aspirations to become entrepreneurs. This gap in tendencies can be explained 
in the light uneven possibilities in different socio-economic contexts. According to the same authors, one third of the students in Serbia has entrepreneurial tendencies and sees it as a potential career choice. This number is significant for a country that has entered the transition process rather late. This group of students sees their society as market economy oriented and they are adopting behavioral patterns it's imposing.

The main question in this article is: Does the current program of education in high schools in Serbia need addition in the form of contemporary teaching materials related to current socio-economic context and with regard to global trend? Likewise, do curricula need radical adaptation or obligatory courses which encourage innovative thinking, new inventions and entrepreneurship skills among high school pupils?

The aim of this research is to form a data base which contains information about entrepreneurial tendencies and affinity of high-schools located in rural municipalities in Vojvodina. The purpose of this article is to analyze the influence of entrepreneurial education on formation of entrepreneurial tendencies among the young. By employing further research, entrepreneurial tendencies could be compared among high-school pupils across the Republic of Serbia, but also among the young in other countries. Concluding remarks from this paper could serve as a guideline for advancement of curricula or at least as an addition to the current ones. This could be done through proposal for alteration and addition of certain parts of Strategy of local economic development of local governments and Strategy of educational development in Serbia until 2020.

\section{Importance of early entrepreneurial education of young people in rural areas}

Entrepreneurship isn't solely business and economic phenomenon (Milojević, Zekić, 2015). It is related to every aspect of human behavior and functioning, regardless of the type of organization, ownership and branch of industry (Grilo, Thurik, 2006). Collection of various qualitative factors such as historical, cultural, political, ideological, psychological and structural could, as well as an educational system which encourages entrepreneurial tendencies, with time boundaries, influence the level of entrepreneurial activity of a country.

Contemporary research in developed countries indicates that early entrepreneurial education in rural areas has a positive influence on decisions of young people to engage in entrepreneurial activities (Schoof, 2006). In this way, the number of so called "preentrepreneurs" is increasing. Entrepreneurial education of the young brings numerous benefits: teaches them how to plan, start and manage their own business (Young, 2014; Oostrebeek, van Praag, Ijsselstein, 2010), sparks creativity and motivates them to transfer their ideas into practice (Fayolle, 2008), exposes the young to real life and prepares them to be responsible, to think and to take risks (Carayannis, Evansm, Hanson, 2003). Authors Korhonen, Komulainen and Räty (2011) see the significance of early entrepreneurial education of the young in creating citizens able to take risks to be concurrent and innovative, hence they would like to stay in rural areas and maybe attract other people to live and work there. 
Introducing entrepreneurship as an integral part of educational program on all study levels (from elementary to university education) aims at acquiring knowledge and a set of cognitive and non-cognitive skills (persistence, creativity) (Heckman, Rubinstein 2001; Gensowski, Heckman, Savelyev, 2011). Furthermore, it increases awareness about entrepreneurship as a career option, but also that entrepreneurship is a suitable call for the young (Peterman, Kenedy 2013; Souitaris, Zerbinati, Al-Laham, 2007).

\section{Entrepreneurship in Serbian education system}

According to available data the number of pupils enrolled in high-schools (in Vojvodina) at the beginning of the school year 2014/15 was 66,372 whereas 32,886 were female pupils. The young in Autonomous Province of Vojvodina can choose to attend grammar schools, vocational schools, mixed schools, art schools, and schools for pupils with special needs. The number of regular schools is 121 ; while there are 10 schools for pupils with special needs, spread across 40 municipalities. Lectures in schools are organized in Serbian, Hungarian, Slovakian, Romanian, Rusyn, and Croatian.

High-school entrepreneurial education in the Republic of Serbia to this date has been organized as a one-term extracurricular activity. One of the examples is "The Junior Achievement Young Enterprise", American program conducted in 50 schools by NGO "European movement in Serbia". Another one is "Youth Entrepreneurship Program", project conducted by "Business Innovation Programs" - a Norwegian non-profit and a Serbian NGO "Civil Initiatives" in 10 vocational schools in Belgrade and Kragujevac. Fifteen high schools for agriculture from various parts of Serbia have introduced Entrepreneurship in their curricula of three-year vocational studies as a part of a pilot program. One of them is Agriculture high school from Futog whose pupils comprise $36 \%$ of the sample in this research. Hence, comparison of the results obtained from this group and the results from the rest of the participants (who are not partaking in the entrepreneurship pilot program) will stress the influence of entrepreneurial education of the young.

According to authors Bogetić, Đorđević and Ćoćkalo (2011), the economic situation in the Republic of Serbia (especially in rural areas) is not providing suitable stimulating ambiance that is helping young people to start their own business. As a reason for this attitude young people have stated some limitations and barriers that are inhibiting their entrepreneurial tendencies: lack of financial means, unstable political and industrial situation, and high taxes. Also, results from the research conducted during 2011 in Serbia with approximately 1200 young people aged between 15 and 30 show that most of the young people in Serbia isn't motivated to engage in entrepreneurship and do not plan their professional career in this area (Stojanović et al., 2012).

Author Đuran (2012) explained how contemporary research supports assumptions that some inventors are simply entrepreneurial personality type and implies how their motivation comes from their personality drives them towards starting their own business. On the other hand, different authors (Vuletić, Stanojević, 2010) are suggesting 
that inventors-entrepreneurs are starting their own businesses by translating research findings into applicable knowledge, driven by both formal and informal education. The above mentioned research implies that the Republic of Serbia needs education system which is going to educate innovative individuals with inventive drive and creative energy who are going to be able to create new industries and products. Furthermore, we need educational institutions that will produce young people with awareness and capability to create new environments such as innovative self-sufficient rural communities that will generate new jobs.

\section{Methodology}

The research about entrepreneurial tendencies of the young from high schools in rural areas in Vojvodina was conducted on data gathered from available literature, scientific papers, journals, books, and internet. Based on theoretical background, authors' previous findings, and consultations with secondary school pedagogy, sociology, and psychology experts, field research was conducted by distributing questionnaires to pupils. The questionnaire consists of four complementary parts. Besides general information, education and personal preferences, and entrepreneurial tendencies, gender equality was also considered by measuring the influence of gender in future career decisions.

Data collection was conducted in the period from September until November 2016 in four vocational schools: Medical High School "Kozma i Damjan" (16\% of the participants) and vocational high school " $4^{\text {th }}$ July" (32\% of the participants) from Vrbas, Technical High School "Mihajlo Pupin" (16\%) from Kula, and Agricultural High School from Futog (36\%). The sample comprises of 400 pupils from the age of 15 to 18 , proportionally distributed according to vocational profiles.

Results of the field research will identify entrepreneurial tendencies of high-school pupils from rural areas in Autonomous Province of Vojvodina. On the other hand, the results from this study could serve as a start for other research. For example, to investigate entrepreneurial tendencies of high-school pupils and university students in Vojvodina, and to compare these tendencies between pupils in rural and pupils in economically more developed areas where entrepreneurship and innovativeness are the core of curricula.

The main assumption of this research is that secondary education that encourages creativity, planning, teamwork, proactivity, and problem solving strengthens entrepreneurial spirit of young people. Another assumption is that young people who come from families with entrepreneurial tradition have stronger entrepreneurial aspirations. This research employs descriptive statistics methods and t-tests to discover significant mean differences among answers on the items of the questionnaire.

\section{Results and Discussion}

High schools that have participated in this research are located in the South Bačka District and this region is classified as significantly rural. However, the region has urban areas, such as city of Novi Sad. 


\section{Descriptive statistics results}

The questionnaire was distributed in cooperation with high-school teachers, pedagogists, and psychologists. The survey was anonymous and voluntary, and gathered data was used exclusively to identify entrepreneurial aspirations of the pupils. The response rate of the questionnaire was $82.5 \%$, i.e. out of 400 distributed questionnaires 330 were filled out. $61.2 \%$ of the participants were male, while $38.8 \%$ were female pupils.

Around $47 \%$ of participants had a very good average mark (3.5 - 4.49 on a scale from 1 to 5), while $25.1 \%$ had excellent average mark (above 4.5 ). Other than standard courses, pupils acquired additional knowledge and skills such as foreign languages (44.5\%), craftsmanship (25.4\%), art and design (22.7\%), and technical skills (22.7\%). As far as extracurricular activities are concerned $55.8 \%$ where involved in helping around the household, agricultural estates, or family farm or business, $39.7 \%$ were engaged in sports or some other activities, and $42.4 \%$ were attending seminars and trainings. Some of the respondents ( $15.1 \%$ of the pupils) were working part-time, and only $4.8 \%$ participated in an international student exchange.

The highest number of participants attended courses for computer skills (34.2\%), and entrepreneurship (9.1\%), which are encouraging results. Each of these courses can influence formation and empowerment of entrepreneurial traits together with selfdirected learning which is related to optimization of different types of lifelong learning. Each individual can choose in which type of organized learning they want to part in and in which way they want to combine them, taking into account their affinities and needs in order to achieve adequate adaptation to societal needs and individual development.

In accordance with the attendance rate of computer courses, as well as contemporary technology trends, $92.1 \%$ of participants stated that they informed themselves using internet and social media. Only $4.8 \%$ of the pupils informed themselves via television, radio, or printed media exclusively, while $19.4 \%$ uses all available media. One of the previous research (van der Merwe, Swardt, 2008) results is that entrepreneurship requires change of perception in the light of new information and application of stateof-the-art technology for their easier collection.

Intensity of engagement in sports, arts, educational, humanitarian and other organizations could indicate the affinity towards team work as a prerequisite for developing entrepreneurial traits (Table 1).

Most of the participants are members of sports organizations $(61.2 \%)$ despite the lack of time (as stated in the comment remarks). They show high affinity and awareness of positive effects of these activities on psycho-somatic wellbeing. Only 13 pupils did not reply to this part of the questionnaire which indicates the lack of the interest for the topic, hence we can classify them as pupils "nonmembers" in sport organizations. Almost half of the pupils (48.2\%) are members of humanitarian organizations, i.e. they're involved in some type of humanitarian activity. Certain pupils did not have any knowledge and information about humanitarian actions but they expressed interest 
in joining them. Beside mentioned organizations, pupils are members in following associations: fishermen's club, gaming clubs, civil police, and political parties.

Table 1. Intensity of engagement of high school pupils in associations and organizations

\begin{tabular}{|l|c|c|c|}
\hline \multirow{2}{*}{\multicolumn{2}{c}{ Type of organization }} & \multicolumn{3}{c|}{ Intensity of engagement } \\
\cline { 2 - 4 } & Not a member & Inactive & Active \\
\hline Sports organization & $28,8 \%$ & $18,5 \%$ & $48,8 \%$ \\
\hline Arts/educational organization & $48,8 \%$ & $30,9 \%$ & $13 \%$ \\
\hline Humanitarian organization & $51,8 \%$ & $23,3 \%$ & $17 \%$ \\
\hline Other & $13,9 \%$ & $5,2 \%$ & $2,1 \%$ \\
\hline
\end{tabular}

Source: Authors based on data analysis from survey research

For about $55 \%$ of pupils, the time spent in school is optimal. Their attitude towards time spent with family and friends is similar, while the only noticeable difference is towards boredom, since $47 \%$ of pupils find that they have insufficient time for idleness. Even though $7.3 \%$ of participants didn't answer the question concerning this issue, results indicate that some pupils have excessive amount of free time that could be under proper guidance utilized for acquiring various skills (Table 2).

Table 2. Time spent in various aspects of life

\begin{tabular}{|l|c|c|c|}
\hline \multicolumn{1}{|c|}{ Time for: } & Insufficient & Optimal & Excessive \\
\hline School & $8,79 \%$ & $54,55 \%$ & $34,85 \%$ \\
\hline Family & $11,52 \%$ & $65,15 \%$ & $21,52 \%$ \\
\hline Friends & $6,97 \%$ & $57,88 \%$ & $33,33 \%$ \\
\hline Idleness & $47,27 \%$ & $27,27 \%$ & $18,18 \%$ \\
\hline
\end{tabular}

Source: Authors based on data analysis from survey research

Results of this research state that $36.36 \%$ of participants have a family tradition of entrepreneurship, while the rest of pupils don't have entrepreneurs in their families.

The highest percentage of pupils (42.12\%) stated that they will maybe or most likely continue their education after finishing high school, while $30.61 \%$ of pupils is certain that they will continue their education, which indicates a certain degree of insecurity regarding decisions whether to continue education, or indicates tendencies of pupils to look for employment.

Majority of high school pupils (60.91\%) would like to find employment in state/public companies which indicates that this type of organization is still most desirable for employment. Even though $36 \%$ of pupils have an entrepreneurial family tradition only $20.3 \%$ is willing to continue family business. These results point out that it is necessary to additionally educate pupils in the subject of entrepreneurship in order to prevent family businesses from shutting down. Moreover, the fact that only $13 \%$ of pupils 
desire to start their own business, and that $7.3 \%$ of pupils plan to live and work abroad is worrying.

In order to examine the influence of gender on future career choices, continuing family business, or starting own business, participants rated gender influence on a scale from 1 to 10 (1 representing lowest, while 10 representing highest impact) (Graph 1).

Graph 1. Gender impact on career choices

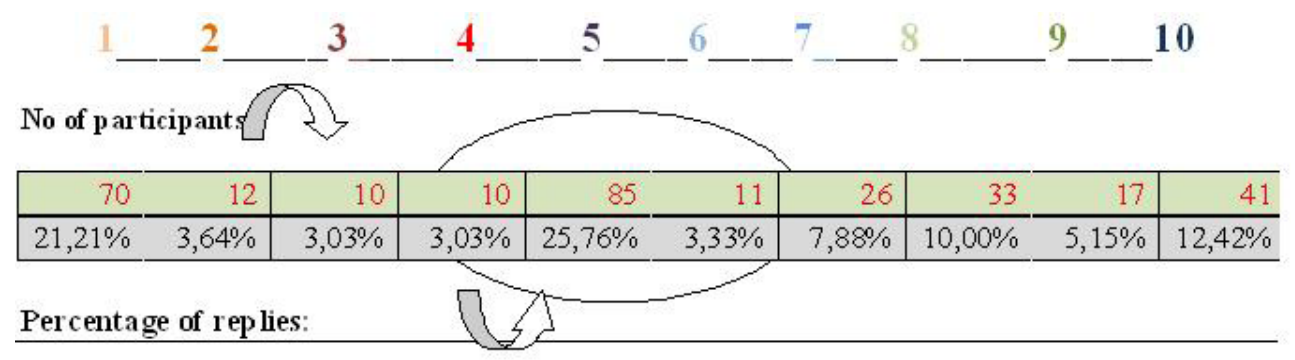

Source: Authors based on data analysis from survey research

Although the answers of the participants vary, they are grouped around the mean values, so we can conclude that gender may have some influence, but it is not crucial when it comes to choosing a career, starting own businesses, or continuing family business.

Comparative analysis: Influence of entrepreneurial education, tradition, and personal entrepreneurial experience between high schools involved in the conducted research

Agricultural High School in Futog offers the course "Entrepreneurship", and 92\% of surveyed pupils from this school are attending it. Only $3.42 \%$ of surveyed pupils from the other three schools have attended or had been attending extracurricular courses for entrepreneurial development.

Results are confirming the assumption that high-school pupils with entrepreneurial family tradition have stronger entrepreneurial tendencies. Opposite of that, author Markov (2006: 48) in his research found no differences between students from the middle class and students from entrepreneurial families.

The number of pupils that exhibited entrepreneurial tendencies, or desire to continue family business is significantly higher in Agricultural High School (46\%) compared to other three schools $(25.5 \%)$. Even though course "Entrepreneurship" is attended only by pupils in the senior year, entrepreneurial attitudes, believes, and values are considered to be transferable across members of the same institutions and organization (Rot, 2010).

In order to identify differences in entrepreneurial tendencies of the young between the pupils who have attended entrepreneurship courses and the ones that have not, dependent sample t-test has been employed (Table 3). Results indicate significant difference $(\mathrm{t} \geq 2.58 ; \mathrm{p}<.01)$ between pupils from the Agricultural high school, and pupils 
from other schools, which suggests that early entrepreneurial education is favorable for developing entrepreneurial tendencies of the young.

Table 3. Mean difference tests

\begin{tabular}{|l|c|c|c|c|c|}
\hline \multicolumn{1}{|c|}{ Pairs (Schools) } & $\begin{array}{c}\text { Mean } \\
\text { value }\end{array}$ & $\begin{array}{c}\text { Standard } \\
\text { deviation }\end{array}$ & T & df & p-level \\
\hline Agricultural - Medical & .83799 & .45608 & 21.427 & 135 & .000 \\
\hline Agricultural - Vocational & -.10042 & .40620 & -2.883 & 135 & .000 \\
\hline Agricultural - Technical & .73757 & .46198 & 18.619 & 135 & .000 \\
\hline
\end{tabular}

Source: Authors based on data analysis from survey research

Pupils find that entrepreneurial learning helps them in enhancing their independence, responsibility, planning skills, and also in developing innovativeness and creativity. One part of the pupils stated that examples of successful entrepreneurs inspired them to pursue a career of an entrepreneur. However, larger portion of respondents (41\%) views the "Entrepreneurship" course as just another subject they attending during their education and do not consider its impact on their career choice as relevant nor on the fact weather they will work in public or private sector.

According to the research results, a strong cross-relation exists between entrepreneurial tendencies and pupils who help around household, family business, or work parttime. According to some authors (Markov, Mirkov, 2006) the influence of previous entrepreneurial experiences on forming entrepreneurial aspirations is strong. Pupils who show stronger entrepreneurial tendencies are pupils who "busted their selfconfidence", also "proved that they can earn income on their own", the ones who "have increased motivation for achievements" and that had already "made some money". On the other hand, pupils with lower entrepreneurial tendencies lack these types of experiences, but most of this group stated that "they learned how to appreciate money".

Earlier research found that young people emphasize the importance of having vocational skills as a prerequisite before starting own business (Viduka, 2014). This attitude reveals the significance in educational system in forming entrepreneurial spirit and also in acquiring comprehension, knowledge, skills, and positive perspective regarding entrepreneurship. Pupils who have approach to these courses and skills have more likely to engage in entrepreneurial career.

\section{Conclusion}

In this research about entrepreneurial aspirations of the high-school pupils in rural areas, the sample of students was comprised of participants of different vocational profiles. In this way, representative sample was created. Furthermore, the sample included pupils that attended the "Entrepreneurship" course, in order to enable the comparison in forming career choices between pupils who are educated in this sense and the ones who are not. All of the participants have very good average marks and have additional knowledge in foreign languages. Besides school activities, many pupils spend their 
time helping their families around household, family farms or business. They are also engaged in acquiring different types of knowledge, most often computer skills.

High school pupils get necessary information via modern ways of communication, such as internet and social networks. They rather become members of sports organizations than any other associations or organizations. Most of the participants rated time spent on school, family, and idleness as optimal, but just a few of them actively prepare themselves for their further education through participating in international student exchange.

Entrepreneurial experience gained from the family business has a strong impact on future orientation of pupils. However, large number of participants sees jobs in governmental and public institutions as most steady, despite numerous layoffs and salary reductions due to ongoing fiscal consolidation in the Republic of Serbia.

The impact of introducing the Entrepreneurship course on the high school level in rural areas is still small. The biggest shift in understanding the importance of the entrepreneurship is visible among teachers and increased participation of schools in various entrepreneurial programs (it is important to note how significant support from the school management is).

Based on the information from this research, authors can conclude that entrepreneurial family tradition and education have strong impact on forming pupils' entrepreneurial tendencies. However, the solution for youth unemployment doesn't lie only in encouraging pupils to start their own business via a single course, but in designing compete high school programs which will shape enthusiasm and innovation tendencies among pupils. These programs need to be created based on data bases that should be continually upgraded with new research data on contemporary business trends.

\section{Literature}

1. Bogetić, S., Đorđević, D., Ćoćkalo, D. (2011): Unapređenje zapošljavanja mladih kao factor razvoja nacionalne ekonomije, Ekonomski horizonti, vol. 13, no. 2, pp. 107126, Ekonomski fakultet Univerziteta u Kragujevcu, Kragujevac, Srbija.

2. Carayannis, E., Evans, D., Hanson, M. (2003): A cross-cultural learning strategy for entrepreneurship education: outline of key concepts and lessons learned from a comparative study of entrepreneurship students in France and the US, Technovation, vol. 23, no. 9, pp. 757-771, Elsevier B.V., Amsterdam, The Netherlands.

3.Đuran, J. (2012): Preduzetnički pristup akademskom obrazovanju, Agroekonomika, vol. 53-54, pp. 80-88, Poljoprivredni fakultet, Novi Sad, Srbija.

4. Fayolle, A. (2008): Entrepreneurship education at a crossroads: towards a more mature teaching field, Journal of Enterprising Culture, vol. 16, no. 4, pp. 325-337, World Scientific Publishing, Singapore.

5. Gensowski, M., Heckman, J., Savelyev, P. (2011): The Effects of Education, Personality, and IQ on Earnings of High-Ability Men, The University of Chicago, Chicago, USA. 
6. Grilo, I., Thurik, R. (2016): Entrepreneurship in the old and new Europe, Scalespaper N200516, [Online] Available at: www.ondernemerschap.nl/pdf-ez/N200516.pdf, accessed on April 1st, 2016.

7. Heckman, J., Rubinstein, Y. (2001): The Importance of Noncognitive Skills: Lessons from the GED Testing Program, The American Economic Review, vol. 91, no. 2, pp. 145-149, American Economic Association, Nashville, Tennessee.

8. Korhonen, M., Komulainen, K., Räty, H. (2011): Bringing up global or local citizens? Pupils' narratives of spatial selves in Finnish entrepreneurship education, Young, vol. 19, no. 1, pp. 45-67, SAGE publishing, Thousand Oaks, California.

9. Markov, S., Mirkov, S. (2006): Preduzetničke težnje studenata u Vojvodini. Filozofski fakultet, Novi Sad, Srbija.

10. Milojević, I., Zekić, M. (2015): Organizaciona struktura preduzeća kao predpostavka konsolidacije bilansa, Oditor, No. 12, pp. 22-28.

11. Napier, G., Rouvinen, P., Johansson, D., Finnbjörnsson, T., Solberg, E., Pedersen, K. (2012): The Nordic Growth Entrepreneurship Review 2012, final report, Nordic Innovation, Oslo, Norway.

12. NIC - Nordic Innovation Centre (2005): Creating Opportunities for Young Entrepreneurship - Nordic examples and experiences, executive summary, Nordic Innovation Centre, Oslo, Norway.

13. Oosterbeek, H., van Praag, M., Ijsselstein, A. (2010): The impact of entrepreneurship education on entrepreneurship skills and motivation, European Economic Review, vol. 54, no. 3, pp. 442-454, Elsevier B.V., Amsterdam, The Netherlands.

14. Peterman, N., Kennedy, J. (2003): Enterprise education: Influencing students' perceptions of entrepreneurship, Entrepreneurship Theory and Practice, vol. 28, no. 2, pp. 129-144, John Wiley \& Sons, Inc., Hoboken, New Jersey.

15. Raposo, M., do Paço, A. (2011): Entrepreneurship education: Relationship between education and entrepreneurial activity, Psicothema, vol. 23, no. 3, pp. 453457, the Psychology Faculty of the University of Oviedo, Oviedo, Spain.

16. Rot, N. (2010): Osnovi socijalne psihologije, Filozofski fakultet, Beograd, Srbija.

17. Rusu, S., Isac, F., Cureteanu, R., Csorba, L. (2012): Entrepreneurship and entrepreneur: A review of literature concepts, African Journal of Business Management, vol. 6, no. 10, pp. 3570-3575, Academic Journal, Ebène, Mauritius.

18. Schoof, U. (2006): Stimulating Youth Entrepreneurship: Barriers and incentives to enterprise start-ups by young people, SEED Working Paper No. 76, International Labour Office, Geneva, Switzerland.

19. Souitaris, V., Zerbinati, S., Al-Laham, A. (2007): Do entrepreneurship programmes raise entrepreneurial intention of science and engineering students? The effect of learning, inspiration and resources, Journal of Business Venturing, vol. 22, no. 4, pp. 566-591, Elsevier B.V., Amsterdam, The Netherlands. 
20. Stevenson, L., Lundström, A. (2001): Paterns and trends in entrepreneurship/SME policy and practice in ten economies. Entrepreneurship Policy for the Future Series, Swedish Foundation for Small Business Research, Stockholm, Sweden.

21. Stojanović, M., Radaković, D., Šolić-Vojinović, M., Bubanja, J. (2012): Državna služba? Ne, hvala, ja sam preduzetnik, Građanske inicijative, Beograd, Srbija.

22. Van der Merwe, S., Swardt, G. (2008): Small business owner-managers 'perceptions of entrepreneurship in the Emfuleni district, South African Journal of Economic and Management Sciences, vol. 11, no. 4, pp. 449-464, University of Pretoria, Pretoria.

23. Viduka, B. (2014): Percepcija mladih o osobinama i sposobnostima potrebnim za preduzetništvo, Poslovna ekonomija, vol. 1/2014, pp. 239-258, Univerzitet Educons, Sremska Kamenica, Srbija.

24. Vuletić, V., Stanojević, D. (2010): Istraživački izveštaj o položaju mladih u Republici Srbiji: Neformalno obrazovanje mladih u Srbiji, Filozofski fakultet, Institut za sociološka istraživanja, Beograd, Srbija.

25. Young, L. (2014): Enterprise for all - the relevance of enterprise in education, Department for Business, Innovation \& Skills, London, UK.

26. Žarković Rakić, J. (2014): Povećanje zaposlenosti u Srbiji: Nekoliko mogućih rešenja. Kako povećati zaposlenost u Srbiji?, Univerzitet u Novom Sadu, Novi Sad, Srbija.

27. www.ec.europa.eu/eurostat (accessed on September 2016). 


\title{
PODSTICANJE PREDUZETNIŠTVA U SREDNJIM ŠKOLAMA: PRIMER RURALNIH SREDINA U VOJVODINI (SRBIJA)
}

\author{
Slavica Otovićc ${ }^{\text {, Dunja Demirovićc }}{ }^{6}$,Kristina Košič ${ }^{7}$, Aleksandra Vujko ${ }^{8}$
}

\begin{abstract}
Rezime
Rano preduzetničko obrazovanje ima pozitivan uticaj na odluke mladih ljudi da se uključe u preduzetničke aktivnosti. Dugoročna nezaposlenost mladih je karakteristika Republike Srbije. Nezaposlenost mladih može biti smanjena usmeravanjem $i$ podsticanjem mladih ljudi da započnu sopstveni biznis, ali oblikovanje preduzetničkih težnji treba da bude primarno. Te težnje moraju biti zasnovane na znanju, veštinama, socijalnom uključivanju i umrežavanju. Obrazovni system treba prilagoditi tako da prati ekonomske $i$ tržišne promene. U ovom radu, istraživanje je sprovedeno u četiri srednje škole koje se nalaze u Autonomnoj Pokrajini Vojvodini. Učenici su dobili upitnik kako bi se ocenile njihove preduzetničke težnje. Na osnovu prikupljenih podataka, mere za menjanje i dopunjavanje planova i programa u srednjim školama se mogu osmisliti. Rano preduzetničko obrazovanje pomaže mladima da izgrade svoje karijere na realnim osnovama koje će biti kompatibilne sa tekućim globalnim trendovima.
\end{abstract}

Ključne reči: preduzetništvo, nezaposlenost, obrazovanje, mladi, Vojvodina (Srbija)

JEL: $Q 13, Q 15$

5 Slavica Otović, MSc, Menadžer za odnose sa javnošću, Opšta bolnica Vrbas, Dr M. Cekica 4, 21460 Vrbas, Srbija, telefon: +38164 802 3215, E-mail: slavicaotovic1@gmail.comn

6 Docent, dr Dunja Demirović, Univerzitet Privredna akademija, Fakultet za ekonomiju i inženjerski menadžment, Cvećarska 2, 21000 Novi Sad, Srbija, telefon: +381642686290, E-mail: demirovic.dunja2@gmail.com

7 Docent, dr Kristina Košić, Univerzitet u Novom Sadu, Prirodno-matematički fakultet, Departman za geografiju, turizam i hotelijerstvo, Trg Dositeja Obradovića 3, 21000 Novi Sad, Srbija, E-mail: tinicaus@yahoo.com

8 Dr Aleksandra Vujko, Predavač, Visoka poslovna škola strukovnih studija, Ulica Vladimira PerićaValtera br. 4, 21000 Novi Sad, Srbija, telefon: +381 64914 26 45, E-mail: aleksandravujko@yahoo.com

EP 2017 (64) 4 (1523-1535) 
ECONOMICS OF

AGRICULTURE

\section{CONTENT}

1. Adriana Radosavac, Desimir Knežević

ECONOMIC IMPORTANCE OF USE

OF PESTICIDES IN WHEAT PRODUCTION . . . . . . . . . . . 1323

2. Berhe Gebregewergs, Muuz Hadush

DOES CLIMATE CHANGE AFFECT PRICE OF VEGETABLES:

EVIDENCE FROM TIGRAI, NORTHERN MOST ETHIOPIA. . . . .1335

3. Grujica Vico, Aleksandra Govedarica-Lučić, Zoran Rajić, Radomir Bodiroga, Ivan Mičić, Silvija Zec Sambol, Marija Mičić

MULTI ATTRIBUTE ASSESSMENT APPROACH

IN VEGETABLE PRODUCTION . . . . . . . . . . . . . . 1355

4. Igor Trandafilović, Vesna Conić, Aleksandra Blagojević

IMPACT OF DEMOGRAPHIC FACTORS ON

ENVIRONMENTALLY CONSCIOUS PURCHASE BEHAVIOUR. . .1365

5. Imre Milán Harcsa

STUDY ON THE POTENTIAL OF SUBCONTRACT

PALINKA DISTILLATION . . . . . . . . . . . . . . 1379

6. Jelena Andrašić, Vera Mirović, Nada Milenković, Branimir Kalaš, Miloš Pjanić

IMPACT OF TAKEOVER PROCESS ON EMPLOYEES -

EVIDENCE FROM FOOD, RETAIL AND FINANCIAL SECTOR . . .1393

7. Jelena Birovljev, Danilo Đokić, Bojan Matkovski, Žana Kleut

ECONOMIC PERFORMANCES OF AGRICULTURE

OF CEFTA AND FORMER CEFTA COUNTRIES . . . . . . . . . . 1413

8. Jelena Marković, Svetlana Stevović

SUSTAINABILITY OF CHEMICAL SOIL QUALITY

IN SOUTHERN MORAVA RIVER VALLEY

IN CORELLATION WITH THE FLOODING $\ldots \ldots \ldots \ldots \ldots$ 
9. Mile Peševski, Zoran Milovančević

THE CHANGES IN THE USAGE OF AGRICULTURAL LAND

IN EASTERN REGION OF REPUBLIC OF MACEDONIA

BETWEEN $1991-2030 \ldots \ldots$. . . . . . . . . . . . . . . . . . . . . . .

10. Odjuvwuederhie Emmanuel Inoni, 'Oraye Dicta Ogisi, Felix Odemero Achoja

PROFITABILITY AND TECHNICAL EFFICIENCY IN HOMESTEAD

CATFISH PRODUCTION IN DELTA STATE, NIGERIA . . . . . . . 1449

11. Olja Munitlak - Ivanović, Jovan Zubović, Petar Mitić

RELATIONSHIP BETWEEN SUSTAINABLE DEVELOPMENT AND

GREEN ECONOMY - EMPHASIS ON GREEN FINANCE

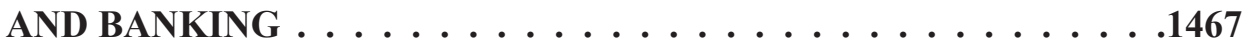

12. Petar Munćan, Dragica Božić

FARM SIZE AS A FACTOR OF EMLOYMENT AND INCOME

OF MEMBERS OF FAMILY FARMS . . . . . . . . . . . . . 1483

13. Rade Popović, Mira Kovljenić

EFFICIENCY OF WHEAT PRODUCTION ON FARMS

IN THE REPUBLIC OF SERBIA . . . . . . . . . . . . . . . . . . . . . . . . .

14. Radovan Damnjanović, Snežana Krstić, Milena Knežević, Svetislav Stanković,

Dejan Jeremić

THE DISCRIMINANT ANALYSIS APPLIED TO THE

DIFFERENTIATION OF SOIL TYPES . . . . . . . . . . . . 1513

15. Slavica Otović, Dunja Demirović, Kristina Košić, Aleksandra Vujko

FOSTERING ENTERPRENUERSHIP AT HIGH SCHOOLS:

A CASE OF RURAL AREAS IN VOJVODINA (SERBIA) . . . . . . .1523

16. Vladimir Ilić, Ivan Bauer, Anastazija Tanja Đelić, Aleksandar Nešković

INSTITUTIONAL SUPPORT FOR STRENGTHENING

ENTREPRENEURSHIP IN AGRICULTURAL PRODUCTION

OF THE REPUBLIC OF SERBIA . . . . . . . . . . . . . . . . . . . . . . . .

17. Boro Krstić, Zorica Vasiljević, Miroslav Nedeljković

INSURANCE CONTRACT AS THE BASIS FOR THE SAFETY OF

AGRICULTURAL PRODUCERS IN THE REPUBLIC OF SRPSKA • . 1555

18. Dejan Sekulić, Aleksandar Petrović, Vladimir Dimitrijević

WHO ARE WINE TOURISTS? AN EMPIRICAL INVESTIGATION

OF SEGMENTS IN SERBIAN WINE TOURISM . . . . . . . . . . . . . 
19. Milan Beslać, Ćorić Goran

FINANCIAL AND PRODUCTION ASPECTS OF GENETICALLY MODIFIED ORGANISMS $\ldots \ldots \ldots \ldots \ldots \ldots \ldots \ldots \ldots$

20. Mlađan Maksimović, Darjan Karabašević, Miodrag Brzaković, Pavle Brzaković THE EFFECTS RESULTING FROM THE APPLICATION OF THE CONCEPT OF THE SUSTAINABLE DEVELOPMENT OF RURAL TOURISM ON STARA PLANINA . . . . . . . . . . . . . . . .1595

21. Vesna Popović, Predrag Vuković, Milivoje Ćosić FOOD SAFETY AND QUALITY POLICY IN THE REPUBLIC OF SERBIA . . . . . . . . . . . . . . . . 1607

22. Radovan Pejanović, Danica Glavaš-Trbić, Mirela Tomaš-Simin PROBLEMS OF AGRICULTURAL AND RURAL DEVELOPMENT IN SERBIA AND NECESSITY OF NEW AGRICULTURAL POLICY . . . .1619

23. Saša Marković, Slavoljub Vujović, Aleksandar Damnjanović MARKETING AND HIGHER EDUCATION CONDITION IN SERBIA . . . . . . . . . . . . . . . . 1635

24. Semir Vehapi, Marina Milanović THE EFFECT OF MARKET ORIENTATION ON BUSINESS PERFORMANCE OF SERBIAN ORGANIC PRODUCERS . . . . . 1651

25. Suad Bećirović, Šemsudin Plojović, Enis Ujkanović, Senadin Plojović CHALLENGES AT STARTING AN AGRIBUSINESS IN THE HILLY MOUNTAINOUS REGIONS OF SOUTHWEST SERBIA . . . . . . . .1669

26. Vladimir Zakić, Vlado Kovačević, Jelena Damnjanović SIGNIFICANCE OF FINACIAL LITERACY FOR THE AGRICULTURAL HOLDINGS IN SERBIA . . . . . . . . . . 1687

27. Željko Bjelajac, Marijana Dukić Mijatović, Željko Vojinović PROTECTION OF LAND IN THE REPUBLIC OF SERBIA AND ECOLOGICAL SECURITY WITH REGARD TO STRATEGIC AND LEGAL FRAMEWORKS . . . . . . . . . .1703 